\title{
HUMAN RESPIRATORY SYNCYTIAL VIRUS DETECTION IN CHILDREN ADMITTED AT A COMMUNITY HOSPITAL IN BOTUCATU, SP, BRAZIL
}

\author{
Patrícia Alves Ramos Bosso후 ;oão Manuel Grisi Candeias²; Karina dos Santos Paduan²; Sandra Mara Queiroz \\ Ricchetti ${ }^{3}$; Antero Frederico Macedo de Miranda ${ }^{3}$; Lígia Maria Suppo de Souza Rugolo ${ }^{3}$; Edison Luiz Durigon ${ }^{1}$; \\ Armando Morais Ventura ${ }^{1 *}$
}

${ }^{1}$ Departamento de Microbiologia, Instituto de Ciências Biomédicas, Universidade de São Paulo, São Paulo, SP, Brasil; ${ }^{2}$ Departamento de Microbiologia e Imunologia, Instituto de Biociências, Universidade Estadual Paulista, Botucatu, SP, Brasil; ${ }^{3}$ Departamento de Pediatria da Faculdade de Medicina, Universidade Estadual Paulista, Botucatu, SP, Brasil

Submitted: December 18, 2003; Returned to authors for corrections: April 22, 2004; Approved: November 09 , 2004

\section{SHORT COMMUNICATION}

\begin{abstract}
Human Respiratory Syncytial Virus (HRSV) is recognized as the single most important pathogen responsible for acute viral infection of the lower respiratory tract in young children. In this study, 84 samples from children under two years of age presenting acute respiratory symptoms were obtained from September 2000 to November 2001. Analysis by immunofluorescence and reverse-transcription followed by PCR, revealed that $18 \%(15 / 84)$ of all the samples were positive for HRSV, in which $80 \%(12 / 15)$ of the cases was observed in children under six months of age and the subgroups A and B co-circulated in the studied period. These are the first data obtained for Botucatu city and seasonality is evident by the higher circulation of the virus between May and July.
\end{abstract}

Key words: Human Respiratory Syncytial Virus (HRSV), RT-PCR, immunofluorescence, seasonality

Human Respiratory Syncytial Virus (HRSV) is the most important etiologic agent of acute respiratory tract infection in infants and young children worldwide, resulting in bronchiolitis, tracheobronquitis, and pneumonia $(6,23)$. HRSV is a pneumovirus of the family Paramyxoviridae, order Mononegavirales. The HRSV (strain A2) genome has 15,222 nucleotides (nt) in length, encoding 10 mRNAs and 11 proteins in the order 3' - NS1 - NS2 - N - P - M - SH - G - F - M2,1/ $\mathrm{M} 2,2-\mathrm{L}-5$ ' $(5,6,10)$. The two major HRSV strain subgroups, A and $\mathrm{B}$, are distinguished primarily by the envelope $\mathrm{G}$ glycoprotein, which shows about $50 \%$ of divergence in amino acids sequence between subgroups (16). In children severe lower respiratory tract disease generally occurs only in the first 2 years of life, but this experience does not protect against less severe forms of HRSV infections such as upper respiratory disease tract and ear infections, by both subgroups (6). HRSV has been also recognized to be an important pathogen in the elderly people and in immunocompromissed patients $(7,20)$. Moreover the attempts of vaccine development were not successful yet $(12,17)$.

HRSV widespread distribution in tropical and subtropical countries is somewhat different with epidemics occurring during late fall, winter or spring (6). Studies in countries such as Australia (14), Uruguay (15), and Brazil demonstrated that the acute respiratory disease are responsible for up to $50 \%$ of children attendance in health care centers, and for $2 / 3$ of the emergencies in hospitals $(2,4,23)$.

Rapid diagnosis methods were developed in order to do HRSV detection, which is important for a correct clinical treatment. This can be done in nasopharyngeal secretions,

*Corresponding author. Mailing address: Departamento de Microbiologia, Instituto de Ciências Biomédicas II, Laboratório de Vetores Virais, Universidade de São Paulo. Av. Prof. Lineu Prestes, 1374, Cidade Universitária. 05508-900, São Paulo, SP, Brasil. E-mail: amventur@icb.usp.br 
recovered by aspiration or nasal washing techniques where infected epithelial cells can be found (11). These viruses usually can be isolated in cell cultures such as HEp-2 (larynx carcinoma) or HeLa (cervical carcinoma) (24). The observation of the cytopatic effect (cell fusion) in conjunction with the indirect immunofluorescent assay (IFA) can be used to confirm the presence of the viral antigens (6). Another advantage of the diagnosis by IFA is the capacity to determine the quality of the specimens $(3,8)$.

RNA genomes can be detected by reverse transcriptionPCR (RT-PCR), and this technique was successfully used for HRSV identification in clinical samples $(3,8,25)$. RT-PCR followed by nested-PCR has been described as a highly sensitive method for viral detection and a useful tool for HRSV diagnosis $(13,22)$.

The purpose of this study was to detect HRSV using IFA and RT-PCR in samples from children admitted at the Hospital das Clínicas da Faculdade de Medicina, Universidade Estadual Paulista, Botucatu, São Paulo, presenting acute respiratory symptoms.

From September 2000 to November 2001, nasopharingeal aspirates (NPs) were collected from 84 children up to 2 years of age, with acute respiratory disease (ARD). The procedure (9) was conducted according to the local Ethics Commission rules and the patients were attended at the emergency service, pediatric wards or intensive care unit. All samples were resuspended in phosphate buffered saline (PBS, $\mathrm{pH}$ 7.2) containing Penicillin/Streptomycin 1000U/mL and Fungizone $50 \mathrm{mg} / \mathrm{mL}$ (Invitrogen, San Diego, CA) immediately after collection and separated in aliquots, one for IFA and the other for RT-PCR.

The diluted specimens were washed twice with PBS by centrifugation at $500 \mathrm{Xg}$ for $10 \mathrm{~min}$ at $4^{\circ} \mathrm{C}$. The pellet was resuspended in PBS and distributed on two slides for screening and typing. A pool of monoclonal antibodies for respiratory viruses (influenza, parainfluenza, adenovirus and HRSV) in a commercially available kit (Chemicon, Temecula, CA, USA) was used for screening. When a HRSV positive sample was obtained, typing in subgroups A or B was done using the MAbs 92-11c and 102-10b, a gift from Dr. Larry Anderson from Centers for Disease Control and Prevention, Atlanta, GA (1). The detection was done with fluorescein-conjugated goat anti mouse serum (Sigma, Saint Louis, MO). The slides were mounted and observed in a fluorescence microscope (Zeiss) using epillumination.

HRSV strain A2 (for use as a positive reaction control) was grown in HEp-2 cells propagated in MEM (Minimal Essential Medium) supplemented with $10 \%$ of Fetal Bovine Serum (CULTILAB, Campinas, SP). Partially purified HRSV was obtained from HEp-2 cells infected with A2 strain supernatant by polyethylene-glycol (Sigma) precipitation (19). RNA was extracted from nasopharyngeal samples, HEp-2 infected cells and from partially purified HRSV, using Trizol® LS (Invitrogen).
Reverse transcription reactions were done using Superscript ${ }^{\mathrm{TMI}}$ and random primers (Invitrogen). The complementary DNAs (cDNAs) were stored at $-70^{\circ} \mathrm{C}$.

PCR reactions were carried out using Taq polimerase (Invitrogen). Primers FV (5' - GTTATGACACTGGTA TACCAACC - 3'), which corresponds to the positions 163 to 186 of the protein F gene, and GR5 (5' - TCCACCAAAAAAACC - 3'), positions 151 to 173 of the protein $\mathrm{G}$ gene, produce an amplified product of $948 \mathrm{bp}$. The conditions were $94^{\circ} \mathrm{C}$ for 5 minutes and 30 cycles of: $94^{\circ} \mathrm{C} / 1$ minute, $55^{\circ} \mathrm{C} / 1$ minute, $72^{\circ} \mathrm{C} / 1$ minute and a final step of $72^{\circ} \mathrm{C}$ for 5 minutes. Nested-PCR reactions were performed using the primers $\mathrm{F1AB}$ ('5CAACTCCATTGTTATTTGCC - 3'), positions 3 to 22 of the F protein gene, and GAB ( 5 ' - YCAYTTTGAAGTGTTCAACTT $3^{\prime}$ ), positions 504 to 524 of the $\mathrm{G}$ protein gene, that produce an amplified product of $488 \mathrm{bp}$ as previously described (18). The conditions were $94^{\circ} \mathrm{C}$ for 5 minutes and 30 cycles of: $94^{\circ} \mathrm{C} / 1$ minute, $51^{\circ} \mathrm{C} / 1$ minute, $72^{\circ} \mathrm{C} / 1$ minute and a final step of $72^{\circ} \mathrm{C}$ for 5 minutes. The DNA fragments were analyzed by electrophoresis in agarose gel, stained with ethidium bromide.

The result of the screening by IFA revealed $18 \%(15 / 84)$ HRSV positive samples, all collected in the year 2001, which demonstrates the importance of this pathogen in the studied population. Further analysis showed that $66.7 \%(10 / 15)$ of the NPs, reacted with MAb for HRSV subgroup A, 6.7\% (1/15) for subgroup B and $26.7 \%$ (4/15) for both antibodies. The relative frequency of HRSV subgroups A and B is variable in annual outbreaks analyzed in different parts of the world, and in general subgroup A is slightly predominant $(1,8)$. Apparently there was no connection among epidemics in different communities and this variable circulation pattern of the HRSV subgroups seems to be a local or regional phenomenon (5).

From the total of HRSV positive results, $80 \%$ (12/15) were obtained from children under six months of age, agreeing with data found in the literature $(4,13,23,26)$. Also it was observed that the number of positive cases of HRSV and ARD decreased significantly with the increase of age (data not shown).

From the 84 samples analyzed, the same ones detected by IFA were found positive by the RT-PCR technique. This is an indication that there is no difference in the sensitivity between these methods and considering the higher cost and difficulties of RT-PCR, IFA seems to be a better option for diagnosis. In Fig. 1 RT-PCR detection is exemplified, and we can see that one of the positive samples (lane 5) presented a pattern with an upper band, also detected in other samples (not shown). Another upper band was also detected in the control with total RNA from infected HEp-2 cells (lane 2). Since this band doesn't appear in the genomic RNA control (lane 1), and in some of the positive samples (lane 6 and other results not shown), or in the negative samples (lanes 3, 4 and neither in other results not shown), we attribute its presence to viral transcripts in infected HEp-2 cells and in some of the samples. 


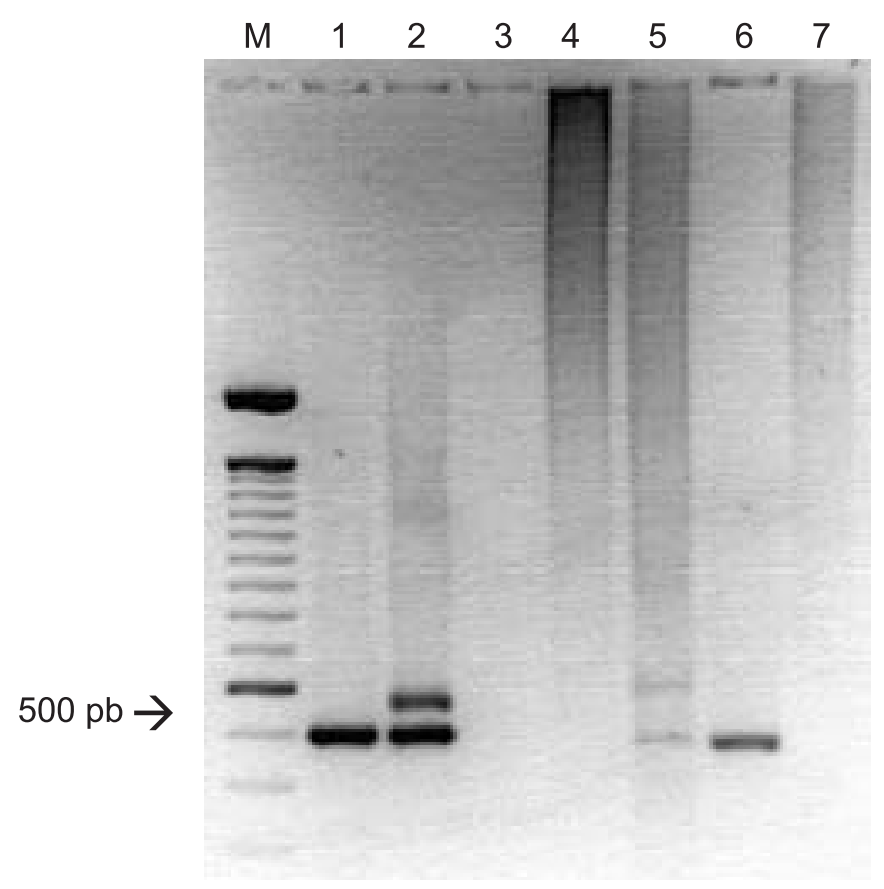

Figure 1. Example of RT-PCR for HRSV detection in clinical samples. Molecular weight marker (M); HRSV A2 genomic RNA (1); HRSV A2 infected cells total RNA (2); clinical samples (3 and 4: negative, 5 and 6: positive) and water as negative control (7). A negative image of agarose gel eletrophoresis is presented.

Brazil is a large country, with broadly diverse regional climate characteristics. While in the north rainfall is the main climatic determinat, temperature variations play a more significant role in the south and southeast. Climate diversity can also be noted among different areas of the southeast region of Brazil, such as more defined cold seasons in the higher lands than in coastal areas of São Paulo and Rio de Janeiro states $(4,27)$. There is a corresponding seasonality of respiratory illnesses that may vary among different regions of the country, and even among geographically different areas within the same region. A prospective study in children from Fortaleza, a coastal northeastern city, showed that the prevalence of respiratory symptoms was high and steady throughout the year, corroborating that point (21).

In Botucatu city, the weather during autumn months (MarchJuly) is mainly characterized by a steady temperature decrease toward the winter, with the lowest temperatures generally registered in July. This was the case of the period analyzed. Published studies have indicated that there is an overall increase in HRSV related illnesses during autumn and winter in subtropical regions of South America (26). In our study this seasonality was characterized with a higher occurrence of positive cases in the months of May, June and July (Fig. 2).

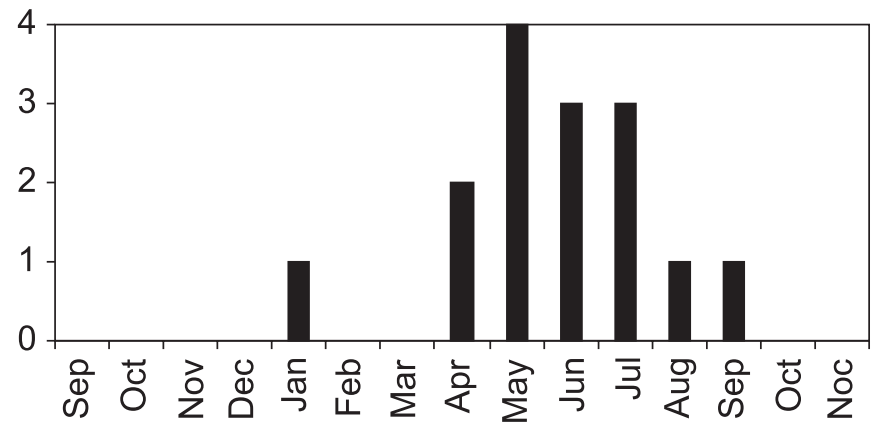

Figure 2. HRSV seasonality. Positive cases in the analyzed period were plotted according to the month of collection, from September of 2000 (left) up to November of 2001.

In conclusion, our results show that in Botucatu city, representing a large area of São Paulo state inlands, HRSV occurrence has a similar pattern of that observed in other cities of Brazil's southeast $(4,27)$.

\section{ACKOWLEDGEMENTS}

This work was supported by grants from FAPESP (process number 00/12261-3) for M.Sc. scholarship and CNPq.

\section{RESUMO}

\section{Detecção de vírus respiratório sincicial humano em crianças hospitalizadas em Botucatu, SP, Brasil}

O Vírus Respiratório Sincicial Humano (VRSH) é descrito como o mais importante patógeno viral causador de doenças respiratórias agudas das vias respiratórias inferiores em crianças. Neste estudo 84 amostras de crianças com idade abaixo dos dois anos apresentando sintomas de doença respiratória aguda, foram obtidas no período de setembro de 2000 a novembro de 2001. Analise por imunofluorescência indireta e transcrição reversa seguida de PCR, revelou que $18 \%$ (15/84) das amostras foram positivas, sendo que em $80 \%$ (12/15) dos casos a detecção de VRSH foi observada em crianças abaixo dos seis meses, e também que os subgrupos A e B co-circularam. Estes são os primeiros dados obtidos para a cidade de Botucatu, sendo que a sazonalidade mostrou-se evidente pela maior circulação desse vírus entre os meses de maio e julho.

Palavras-chave: Vírus Respiratório Sincicial Humano (VRSH), RT-PCR, imunofluorescência, sazonalidade

\section{REFERENCES}

1. Anderson, L.J.; Hierholzer, J.C.; Tsou, C.; Hendry, R.M.; Fernie, B.F.; Stone, Y.; McIntosh, K. Antigenic characterization of 
respiratory syncytial virus strain with monoclonal antibodies. $J$. Infect. Dis., 151:626-633, 1985.

2. Andrade, C.L.; Szwarcwalk, C.L. Spatial analysis of early neonatal mortality in the municipality of Rio de Janeiro, 1995-1996. Cad. Saude. Publica., 17:1199-1210, 2001.

3. Cheeseman, S.H.; Pierik, L.T.; Leombruno, D.; Spinos, K.E.; McIntosch, K. Evaluation of a commercially available direct immunofluorescence staining reagent for the detection of respiratory syncytial virus in respiratory secretions. J. Clin. Microbiol., 24:155156, 1986.

4. Cintra, O.A.L.; Owam, A.; Machado, A.A.; Cervi, M.C.; Figueiredo, L.T.M.; Rocha, G.M.; Siqueira, M.M.; Arruda, E. Occurrence and Severity of Infections Caused by Subgroup A and B Respiratory Syncytical Vírus in Children in Southeast Brazil. J. Med. Virol., 65:408-412, 2001

5. Collins, P.L.; Hill, M.G.; Cristina, J.; Grosfeld, H. Transcription elongation factor of respiratory syncytial virus, a nonsegmented negative-strand RNA virus. Proc. Natl. Acad. Sci. USA., 93:81-85, 1996.

6. Collins, P.L.; McIntosh, K.; Chanock, R.M. Respiratory Syncytial Virus. In: Fields, B.N.; Knipe, D.M.; Howley, P.M.; Chanock, R.M.; Melnick, J.L.; Monath, T.P.; Roizman, B.; Strauss, S.E. (eds.). Fields Virology, Lippincott-Raven Publishers, Philadelphia, 1996, p.13131351

7. Falsey, A.R. Respiratory syncytial virus infection in older persons. Vaccine, 16:1775-1778, 1998.

8. Freymuth, F.; Eugene, G.; Vabret, A.; Petitjean, J.; Gennetay, E.; Brouard, J.; Duhamel, J.F.; Guillois, B. Detection of respiratory syncytial virus by reverse transcription-PCR and hybridization with a DNA enzyme immunoassay. J. Clin. Microbiol., 33:3352-3355, 1995.

9. Gardner P.S.; McQuillin, J.; McGuckin, R. -1968. The late detection of respiratory syncytial virus in cells of respiratory tract by immunofluorescence. J. Hyg., 68:575-580, 1970.

10. Grosfeld, H.; Hill, M.G.; Collins, P.L. RNA replication by respiratory syncytial virus (RSV) is directed by the N, P and L proteins, transcription also occurs under these conditions but requires RSV superinfection for efficient synthesis of full-length mRSN. J. Virol., 69:5677-5686, 1995

11. Hall, C.B.; Douglas, R.G. Jr. Clinical use a method for the isolation of respiratory syncytial virus. J. Infect. Dis., 131:1-5, 1975.

12. Hall, C.B. Prospects for a respiratory syncytial virus vaccine. Science, 265:1393-1394, 1994

13. Henkel, J.H.; Aberle, S.W.; Kundi, M.; Popow-Kraupp T.; Improved detection of respiratory syncytial virus in nasal aspirates by seminested RT-PCR. J. Med. Virol., 53:366-371, 1997.

14. Hierholzer, J.C.; Tannock, G.A.; Hierholzer, C.M.; Coomb, R.A.; Kennet, M.L.; Phillpps, P.A.; Gust, I.D. Subgrouping of respiratory syncytial virus strain from Australia and Papua New Guinea by biological and antigenic characteristics. Arch. Virol., 136:133-147, 1994.
15. Hortal, M.; Meny, M.; Russi, J.C.; Chiparelli, H. Meteorological variables and occurrence of respiratory syncytial virus from Uruguay. Res. Virol., 144:405-408, 1993.

16. Johnson, P.R.; Olmsted, R.A.; Prince, G.A.; Murphy, B.R.; Alling, D.W.; Walsh, E.E. Antigenic relatedness between glycoproteins of human respiratory syncytial virus subgroups A and B: evaluation of the contributions of $\mathrm{F}$ and $\mathrm{G}$ glycoproteins to immunity. J. Virol., 61:3163-6, 1987

17. Kneyber, M.C.; Kimpen, J.L. Advances in respiratory syncytial virus vaccine development. Curr. Opin. Investig. Drugs., 5:163-70, 2004.

18. Peret, T.; Hall, C.B.; Hammond, G.W.; Piedra, P.A.; Sullender, W.M.; Tsou, C.; Anderson, L.J. Circulation patterns of group A and B human respiratory syncytial virus genotypes in 5 communities in North America. J. Infect. Dis., 181:1891-1896, 2000.

19. Pringle, C.R. Pneumoviruses. In: Mahy, B.W.J. (ed.). Virology: a practical approach. IRL Press, Oxford, 1985, p.95-117.

20. Soldatou, A.; Davies, E.G. Respiratory virus infections in the immunocompromised host. Paediatr. Respir. Rev., 4:193-204, 2003.

21. Souza, L.S.; Ramos, E.A.; Carvalho, F.M.; Guedes, V.M.; Souza, L.S.; Rocha, C.M.; Soares, A.B.; Velloso, L.deF.; Macedo, I.S.; Moura, F.E.; Siqueira, M.; Fortes, S.; de Jesus, C.C.; Santiago, C.M.; Carvalho, A.M.; Arruda, E. Viral respiratory infections in young children attending day care in urban Northeast Brazil. Pediatr. Pulmonol., 35:184-191, 2003.

22. Stockton, J.; Ellis, J.S.; Saville, M.; Clewley, J.P.; Zambon, M.C. Multiplex PCR for typing and subtyping influenza and respiratory syncytial viruses. J. Clin. Microbiol., 36:2990-2995, 1998.

23. Sutmoller, F.; Ferro, Z.P.; Asensi, M.D.; Ferreira, V.; Mazzei, I.S.; Cunha, B.L. Etiology of acute respiratory tract infections among children in a combined community and Hospital study in Rio de Janeiro. Clin. Infect. Dis., 20:854-860, 1995.

24. Tristram, D.A.; Welliver, R.C. Respiratory syncytial virus. In: Diagnostic Procedure for viral, rickttsial and chamydial infections. American Public Association, 7. ed. Washington: American Public Health., 1996, p.539-552.

25. Van Milaan, A.J.; Sprenger, M.J.; Rothbarth, P.H.; Brandenburg, A.H.; Masurel, N.; Claas E.C. Detection of respiratory syncytial virus by RNA-polymerase chain reaction and differentiation of subgroups with oligonucleotide probes. J. Med. Virol., 44:80-87, 1994.

26. Vieira, S.E.; Gilio, A.E.; Miyao, C.R.; Pahl, M.M.; Lotufo, J.P.; Hein, N.; Betta, S.L.; Durigon, E.L.; Botosso, V.F.; Ejzenberg, B.; Okay, Y. Nosocomial respiratory syncytial virus infection in a pediatric ward. Infect. Control. Hosp. Epidemiol., 24:468-469, 2003.

27. Vieira, S.E.; Stewien, K.E.; Queiroz, D.A.; Durigon, E.L.; Torok, T.J.; Anderson L.J.; Miyao, C.R.; Hein, N.; Botosso, V.F.; Pahl, M.M.; Gilio, A.E.; Ejzenberg, B.; Okay, Y. Clinical patterns and seasonal trends in respiratory syncytial virus hospitalizations in Sao Paulo, Brazil. Rev. Inst. Med. Trop. Sao Paulo., 43:125-31, 2001. 